\title{
PAGRINDINĖS TEISMO PSICHIATRIJOS PACIENTU REHOSPITALIZACIJOS PRIEŽASTYS
}

\author{
Jolanta Navickiené $\dot{1}^{1}$ Edmundas Vaitiekus ${ }^{2}$ \\ ${ }^{1}$ Viešoji įstaiga Rokiškio psichiatrijos ligonine, ${ }^{2}$ Baltijos tarptautine akademija
}

Raktažodžiai: teismo psichiatrijos pacientas, rehospitalizacija.

\begin{abstract}
Santrauka
Psichikos ligomis serga įvairaus amžiaus, išsilavinimo, tautybių vyrai ir moterys. Pastaraisiais dešimtmečiais vykdoma daug tyrimų, kuriuose nagrinejjami biologiniai, psichologiniai bei socialiniai veiksniai, turintys itakos psichikos sutrikimams bei psichikos negalią turinčių asmenų rehospitalizacijai. Šiame straipsnyje, remiantis mokslinès literatūros analize bei VŠI Rokiškio psichiatrijos ligoninejje atliktais tyrimais, ịvardijamos teismo psichiatrijos pacientu (nepakaltinamų asmenų) rehospitalizacijos priežastys. Teismo psichiatrijos pacientų rehospitalizacijos priežastis sąlygoja tarpusavyje sąveikaujančių veiksnių visuma: kiekybiniai ir kokybiniai socialinio tinklo pokyčiai, užimtumo stoka, bedarbystè, ribotos socialinio dalyvavimo galimybès.
\end{abstract}

\section{Ivadas}

Psichikos sveikata - viena didžiausių ir pažeidžiamiausių vertybių šiuolaikinëje visuomenèje. Visuomenèje vyrauja nuostatos, jog asmenys, sergantys psichikos liga, - pavojingi sau ir visuomenei. Psichiatrijos problemomis didžiausias susidomèjimas kyla tik tada, kai psichikos sutrikimų turintys asmenys įvykdo nusikalstamą veiką. Tokie įvykiai visuomenejje sukelia pasipiktinimą, baimę, tačiau remiantis statistika galima teigti, kad psichikos negalią turintys asmenys sunkių nusikaltimų įvykdo daug mažiau nei sveiki žmonès. Nusikalstamumas - socialinis reiškinys, kurio išvengti nepavyksta nei vienai valstybei. Ypač didelè problema - pakartotinai nusikalstantys asmenys. Mokslinėse studijose diskutuojama, kokie rizikos veiksniai yra susiję su pakartotiniu nusikalstamumu, nes nusikalstamumo prevencijos metodai atskirose šalyse skirtingi. Nusikalstamumo prevencijos metodai priklauso nuo ịvairiu teisinių, ekonominiu, socialinių, religiniu ir kitokių priežasčių. Mokslinių tyrimų rezultatai rodo, kad geriausiai pakartotinį nusikalstamumą prognozuoja statiški veiksniai, tačiau taikant psichosocialinès reabilitacijos programas svarbesni yra dinamiški veiksniai.

Iki Lietuvos Respublikos nepriklausomybès atkūrimo asmenys, įvykdę visuomenei pavojingą veiką ir pripažinti nepakaltinamais, specialaus stebejimo sąlygomis buvo gydomi Kaliningrado srities Černiachovsko specialaus tipo psichiatrijos ligoninejje. Kuriant Lietuvos teisinę valstybę, buvo sprendžiamas ir PMP (priverčiamosios medicinos priemonès) taikymo klausimas. Šiuo tikslu 1994 m. Rokiškio psichiatrijos ligonineje ịkurtas 80 vietų specialaus režimo psichiatrijos skyrius, kuriame pradėti gydyti įvykdę nusikaltimus ir turintys psichikos negalią asmenys sustiprinto ir griežto stebėjimo sąlygomis. Dabartiniu metu Lietuvoje stacionarinis stebejimas bendro, sustiprinto ir griežto stebèjimo sąlygomis taikomas vienoje specializuotoje psichikos sveikatos priežiūros ịstaigoje - Rokiškio psichiatrijos ligoninejje. Ligoninèje pacientai gydomi ilgą laiką, tačiau čia sudarytos gydymo ir psichosocialinès reabilitacijos sąlygos, atsižvelgiant ị teismo nutartimi skirtas stebejjimo sąlygas. Pagal BK 98 str. 6 d., ligoninès administracija ne rečiau kaip kartą per šešis ménesius kreipiasi ị teismą su teikimu dèl PMP taikymo pratęsimo, rūšies pakeitimo ar jų taikymo panaikinimo. Teismui PMP stacionare pakeitus į ambulatorini stebèjimą pirminès psichikos sveikatos priežiūros sąlygomis, asmuo iš ligoninès išleidžiamas su artimaisiais arba apgyvendinamas socialinès globos namuose [2]. Apie TPP (teismo psichiatrijos paciento) paleidimą ligoninès administracija informuoja Socialinès rūpybos skyrių ir Psichikos sveikatos centrą pagal paciento gyvenamają vietą [4]. PMP taikymas yra teismo kompetencija, tačiau šių priemonių vykdymas yra neatsiejamas nuo sveikatos priežiūros sistemos. PMP taikymo trukmè siejama su asmens psichikos būkle. Teismas, nagrinėdamas taikomos PMP panaikinimą, neturi spręsti socialinio pobūdžio klausimų. Tam būtinas ịstaigų, užtikrinančiu TPP tolesnę priežiūrą ir reabilitaciją, steigimas, nes dalis pacientų sugrižta ị ịstaigą ir vèl taikomos PMP (2017 m. 7,2 \% padaugėjo asmenų Rokiškio psichiatrijos ligoninèje 
(lyginant su 2015 m.), kuriems pakartotinai taikomos PMP 3-4 ir daugiau kartų).

Naujausiuose moksliniuose tyrimuose, nagrinėjančiuose pasikartojančio nusikalstamo elgesio prigimtị ir jo priežastis, dažniausiai skiriami konkretūs teisès pažeidèjo pakartotinio nusikalstamumo rizikos veiksniai, kurie skirstomi ị dvi grupes. Viena iš jų yra statiniai veiksniai (laikui bègant nesikeičia), antroji - dinaminiai (besikeičiantys). Dinaminiai rizikos veiksniai dar apibūdinami kaip kriminogeniniai poreikiai [8]. Juos patenkinus sumažeja pakartotinio nusikalstamumo rizika. Mokslinèje literatūroje statiniams rizikos veiksniams priskiriama kriminalinio elgesio istorija bei teisès pažeidejo amžius pirmojo nusikaltimo metu. Ne mažiau reikšmingas statinis veiksnys - šeimos kriminalinè istorija. Jeigu asmens šeimos nariai pažeidinèjo įstatymus, jų elgesys buvo asocialus, tai asmens vaikysteje ar paauglysteje išmoktas nusikalstamas elgesys turi tendenciją išlikti ir vèliau. Dinaminiai rizikos veiksniai: išsilavinimas, gyvenamoji vieta, socialiniai santykiai su partneriu ir artimaisiais, darbas, finansai, psichikos sveikata, alkoholio ir narkotikų vartojimas. Statiniai veiksniai yra stabilūs, jų pakeisti negalima, todèl jie negali būti asmens iggalinimo objektu. Pakartotinio nusikaltimo rizika gali būti koreguojama orientuojantis ị dinaminių rizikos veiksnių vertinimą ir koregavimą [8]. Būtina nustatyti pagrindines TPP rehospitalizacijos priežastis, sukurti ir įdiegti efektyvią teismo psichiatrijos paslaugų sistemą, apimančią TPP gydymą, reabilitacinę veiklą ir saugią reintegraciją i visuomenę.

I pacientą orientuota, maksimaliai individualizuota, tęstinè (nenutrūkstama) sveikatos priežiūra yra kokybiškos sveikatos priežiūros pagrindas. Galima išskirti pagrindines priemones, leidžiančias sumažinti rehospitalizacijas:

- ịvertinti hospitalizuotų pacientų riziką pakartotinei hospitalizacijai, atsižvelgiant ị socialinius demografinius veiksnius, sveikatos priežiūros veiksnius bei ligos sunkumą;

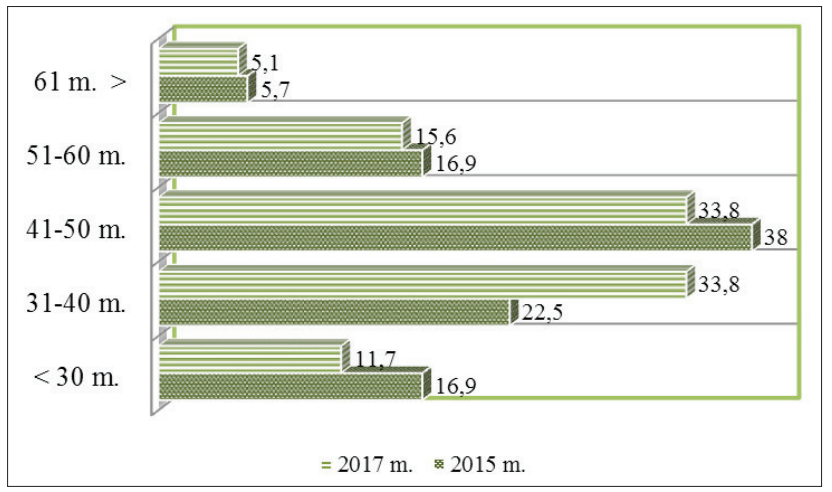

1 pav. TPP pasiskirstymas pagal amžiaus grupes 2015 ir 2017 m. (procentais)
- numatyti galimus praradimus ir naudą, mažinant pakartotines hospitalizacijas [1].

Pakartotinei hospitalizacijai svarbios trys sudedamosios: paskutinis hospitalizacijos epizodas ir jo rezultatai; paciento individualios charakteristikos ir jų pokyčiai po išrašymo bei sveikatos priežiūros aplinka ir organizacijų galimybès; priežiūra po išrašymo (pakartotinès hospitalizacijos prieinamumas ir kt.) [1].

Darbo tikslas - nustatyti pagrindines TPP rehospitalizacijos priežastis.

\section{Tyrimo medžiaga ir metodas}

2015 m. (05-07 mèn.) ir 2017 m. (03-04 mèn.) atlikti sociologiniai tyrimai VŠI Rokiškio psichiatrijos ligoninèje. Tyrimo metodas - interviu su TPP ir dokumentų (teismo psichiatrijos, teismo psichologijos ekspertizių aktų, teismo nutarčių, buities ir gyvenimo sąlygų patikrinimo aktų, raštų iš ịvairių institucijų ir kt.) analizè. Tyrime dalyvavo 148 TPP (2015 m. - 71, 2017 m. - 77), kuriems taikomos PMP griežto, sustiprinto ir bendro stebejjimo sveikatos priežiūros skyriuose.

\section{Tyrimo aprašymas ir rezultatai}

Atsižvelgiant ị aukščiau išdėstytą tyrimo metodą detaliau nagrinèti nepakaltinamų asmenų apklausos rezultatai. Pirmiausia buvo svarbu charakterizuoti tyrime dalyvavusius asmenis.

Respondentų sociodemografinè charakteristika. Tyrime dalyvavo 148 TPP, iš jų 93\% vyrų $(\mathrm{N}=137)$ ir $7 \%$ moterų $(\mathrm{N}=11)$. Pagal amžių pasiskirstymas ịvairus - didžiausią TPP grupę (1 pav.) sudaro asmenys, kurių amžius 31-50 m. Iš 1 paveiksle pateiktų duomenų matyti, kad $2017 \mathrm{~m}$. padaugèjo respondentų, kurių amžius 31-40 m. ir sumažèjo TPP iki 30 metų.

Respondentų biologinè šeima. 2017 m. PMP taikomos $20 \%$ daugiau nei $2015 \mathrm{~m}$. tiems TPP, kurie biologineje šeimoje augo kartu su broliais ir seserimis, bei $20 \%$ mažiau tiems, kurie šeimoje augo vieni (be brolių ir seserų).

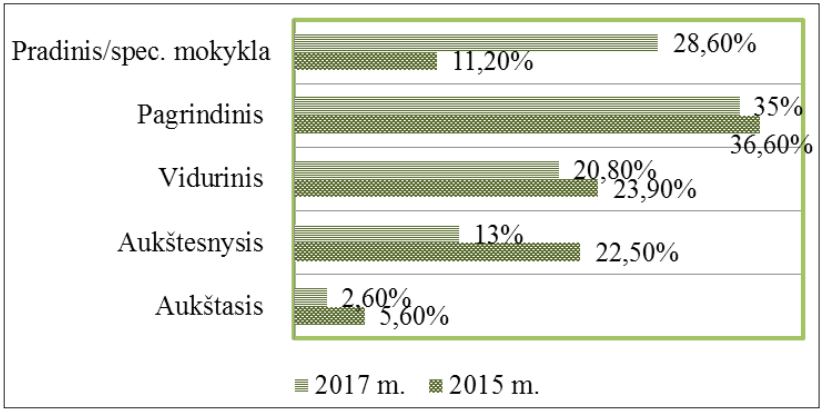

2 pav. TPP pasiskirstymas pagal išsilavinimą 2015 ir 2017 m. 
Išsilavinimas. Lyginant dvejų metų tyrimo rezultatus matyti, kad TPP išsilavinimas tapo žemesnis, 2017 m. 17\% padaugejo žemesnį išsilavinimą turinčių respondentų bei $5 \%$ sumažèjo profesinès kvalifikacijos neturinčių respondentų (2015 m. - 45,6\%,: 2017 m. - 41,6\%). Tiriamuju igytas išsilavinimas atsispindi 2 paveiksle.

Sveikatos būklè. Pakartotinei hospitalizacijai ịtakos turi diagnozè bei darbingumo lygis. Daugeja TPP, kuriems nustatytas mažesnis darbingumo lygis $(2015$ m. 7\%, o 2017 m. 10,4 \% respondentų nustatytas $0-25 \%$ darbingumo lygis). Pagal diagnozę išsiskiria viena iš pagrindiniu grupių F20-28. $2017 \mathrm{~m} .7 \%$ padaugejo tyrime dalyvavusių asmenų, turinčių minètą F20-28 ir 4,5\% F70-79 diagnozę turinčių asmenų. 5\% padaugèjo respondentų, nepripažistančių, jog serga psichikos liga.

Šeimynine padètis ir socialiniai santykiai. Pagal vedybinį statusą TPP situacija tik nežymiai pakito. Pakartotinai taikomos PMP daugiausia (2015 m. - 69\%; 2017 m. - 72,7\%) nevedusiems ir netekejusioms TPP. Iki PMP taikymo 2017 $\mathrm{m}$. gyveno su tévais $8 \%$ asmenų daugiau nei $2015 \mathrm{~m}$. bei sumažejo (2015 m. - 31\%; 2017 m. - 16,9\%) asmenų, gyvenusių ar atvykusių iš socialinès globos namų. 5\% padaugejo respondentų, kuriems pakartotinai taikomos PMP, kurių šeimose buvo smurtaujama bei buvo piktnaudžiaujama alkoholiu. 15\% ( $\mathrm{N}=22)$ daugiau TPP teigia, kad ,artimieji/ tèvai buvo teisti“.

Socialinių ryšiu ir PMP sąsajos. Lyginant 2015 ir 2017 metų tyrimų duomenis, matyti, jog $2015 \mathrm{~m}$. respondentų socialiniai ryšiai su artimaisiais iki PMP taikymo buvo mažiau tvirti nei 2017 m. PMP taikymo metu 2017 m. respondentai teigia, jog santykiai yra tvirti ir rezultatas yra ženkliai geresnis nei 2015 m. Tačiau PMP taikymo metu socialiniai ryšiai tiek 2015 m., tiek 2017 m. su artimaisiais pablogèjo (1 lentelè). Socialinių ryšių palaikymo su draugais, bendruomenès nariais situacija dar sudètingesnè. Jei $2015 \mathrm{~m}$. iki PMP taikymo tvirtus socialinius ryšius su draugais/pažįstamais palaikè 50,7\%, o $2017 \mathrm{~m}$. - beveik $80 \%$ respondentų, tai po PMP taikymo 2015 m. - 88,7\%, 2017 m. - 80,5\% respondentų teigia, kad santykiai su draugais tapo fragmentiški arba nutrūko.

1 lentelè. TPP pasiskirstymas pagal socialinių ryšių palaikymą su šeimos nariais /artimaisiais iki ir po PMP taikymo

\begin{tabular}{|l|l|l|l|}
\hline \multicolumn{2}{|l|}{$\begin{array}{l}\text { Socialiniai ryšiai su šeimos } \\
\text { nariais /artimaisiais }\end{array}$} & $\begin{array}{l}\text { I ki PMP } \\
\text { taikymo }\end{array}$ & $\begin{array}{l}\text { PMP taikymo } \\
\text { metu }\end{array}$ \\
\hline \multirow{2}{*}{ Tvirti } & $2015 \mathrm{~m}$. & $39,5 \%$ & $19,7 \%$ \\
\cline { 2 - 4 } & $2017 \mathrm{~m}$. & $49,4 \%$ & $36,4 \%$ \\
\hline $\begin{array}{l}\text { Fragmentiški / san- } \\
\text { tykių nėra }\end{array}$ & $2015 \mathrm{~m}$. & $60,5 \%$ & $80,3 \%$ \\
\cline { 2 - 4 } & $2017 \mathrm{~m}$. & $50,6 \%$ & $63,6 \%$ \\
\hline
\end{tabular}

Gyvenamoji vieta bei gyvenamasis būstas. Tyrimo duomenys rodo, kad $2017 \mathrm{~m}$. PMP pakartotinai taikomos buvo $15 \%$ daugiau tiems TPP, kurie gyveno kaime ir $21 \%$ daugiau gyvenusiems tėvų ar artimujų namuose. 13\% sumažejo respondentų, kurie gyveno socialinės globos namuose.

Darbinis užimtumas, nedarbo priežastys ir asmeninès pajamos. Remiantis tyrimo duomenimis, galima teigti, kad TPP tampa mažiau aktyvūs darbo rinkoje. Iki PMP taikymo 2015 m. 56,3\% tiriamujų dirbo, po PMP taikymo i darbo rinką grįžo 21,1\% TPP. 2017 m. duomenys rodo, kad iki PMP taikymo dirbo mažesnis procentas $(55,8 \%)$ tyrime dalyvavusių asmenų, o po PMP taikymo darbo rinkoje dalyvavo tik 13\% TPP (8\% mažiau nei 2015 m.). Aiškinantis nedarbo priežastis, paaiškejjo, jog po paskutinio PMP taikymo stacionare $2015 \mathrm{~m}$. respondentai daugiau akcentavo, jog nedarbo priežastys susiję su bloga sveikata, o iš $2017 \mathrm{~m}$. atlikto tyrimo gautų duomenų matyti, kad 5\% padaugejjo TPP, kurie teigia, jog „nerado darbo“, bei $25 \%$ padaugèjo respondentu, kurie teigia, jog „dirbti nenorejo“. Taigi, daugèja TPP, nenorinčiu dalyvauti darbo rinkoje. Atliekant tyrimą, buvo aiškinamasi ir kokias pajamas TPP gauna po PMP taikymo stacionare. Remiantis tyrimų rezultatais, galima teigti, kad $2015 \mathrm{~m}$. beveik $15 \%$ respondentų daugiau nei $2017 \mathrm{~m}$. gavo netekto darbingumo pensiją, o $2017 \mathrm{~m}$. beveik $12 \%$ daugiau nei $2015 \mathrm{~m}$. gavo socialinę pašalpą. Lyginant dviejų tyrimų rezultatus pastebèta, jog daugèja TPP, kurie po PMP stacionare negauna jokių pajamų.

Piktnaudžiavimas alkoholiu ir psichotropinėmis medžiagomis. 2017 m. 14\%, o 2015 m. 17\% respondentų teigè, kad po PMP taikymo stacionare vartojo narkotikus. $2017 \mathrm{~m}$. $61 \%$, o 2015 m. 54\% TPP pakartotiną nusikalstamą veiką ìvykdè būdami apsvaigę nuo alkoholio, narkotikų ar kitų psichotropinių medžiagų.

Ivykdyta nusikalstama veika ir PMP taikymo trukmè. Iš tyrimo rezultatų matyti, kad pakartotinai taikomų PMP stacionare trukmé ilgeja lyginant su pirmą kartą taikytomis PMP. 14\% padaugèjo TPP, kuriems PMP taikomos iki 1 metų, 5,2\% daugiau respondentų, kurių gydymosi trukmè iki 3 metų. Atliekant tyrimą, buvo analizuojama TPP įvykdyta nusikalstama veika, dèl kurios pakartotinai taikomas PMP.

2 lentelè. TPP pasiskirstymas pagal artimujų ir institucijų 2015 ir $2017 \mathrm{~m}$. teiktą paramą

\begin{tabular}{|l|c|c|c|}
\hline Paramą turèjo & & Taip & Ne \\
\hline \multirow{2}{*}{ Artimujų } & $2015 \mathrm{~m}$. & $63,4 \%$ & $36,6 \%$ \\
\cline { 2 - 4 } & $2017 \mathrm{~m}$. & $71,4 \%$ & $28,6 \%$ \\
\hline \multirow{2}{*}{ Institucijų } & $2015 \mathrm{~m}$. & $97,2 \%$ & $2,8 \%$ \\
\cline { 2 - 4 } & $2017 \mathrm{~m}$. & $67,5 \%$ & $32,5 \%(\mathrm{~N}=25)$ \\
\hline
\end{tabular}


Lyginant įvykdytą pirmą nusikalstamą veiką su kitomis, galima pastebėti, kad pirmos PMP yra taikomos už sunkesnes nusikalstamas veikas (14,3\% - nužudymai, $33,8 \%$ - pasikẻsinimas nužudyti, 29,9\% - vagystès ir t.t.), o paskutinès PMP taikomos daugiausia (53\%) už ambulatorinio stebėjimo pirminès psichikos sveikatos priežiūros sąlygų pažeidimą ambulatorinio PMP taikymo metu ( $2 \%$ - nužudymai, $22 \%$ - pasikèsinimas nužudyti, $3 \%$ - vagystès ir t.t.).

Parama po PMP taikymo stacionare. $2017 \mathrm{~m}$. artimuju paramos sulauke 8\% TPP daugiau nei $2015 \mathrm{~m}$. Analizuojant artimujų teikiamą paramą pastebima, kad 57\% TPP gavo ir psichologinę, ir finansinę paramą, $14,4 \%$ turèjo tik psichologinị palaikymą, o 28,6\% (22 iš 77) TPP nesulaukè jokios artimujų paramos. Lyginant 2 metų rezultatus, matyti, kad institucijų paramos $2017 \mathrm{~m}$. sulaukè beveik 30\% tyrime dalyvavusių asmenų mažiau nei 2015 m., 32,5\% (t.y. 25 iš 77) nesulaukè, negavo jokios institucijų paramos (2 lentelè).

Analizuojant paramą teikusių i̇staigų pasiskirstymą, nustatyta, kad $2015 \mathrm{~m} .63 \%$ paslaugų teikè PSC, 30\% - SGN ir 4\% - savivaldybės bei seniūnijos. $2017 \mathrm{~m}$., remiantis tyrimo duomenimis, PSC teikiamų paslaugų skaičius sumažèjo iki $42 \%$, SGN iki $26 \%$, o savivaldybių bei seniūnijų teikiamos paslaugos sudare $0 \%$.

Tyrimo metu domètasi, kokias paslaugas TPP gavo priverstinio ambulatorinio stebejjimo metu. Remiantis tyrimo duomenimis, galima teigti, kad $2017 \mathrm{~m}$. TPP institucijų teikiamų paslaugų gavo mažiau nei $2015 \mathrm{~m}$., nes 32\% tyrime dalyvavusių asmenų negavo jokių psichosocialinių paslaugų (2015 m. paslaugų negavo tik 2,8\%). $2017 \mathrm{~m}$. medicininių paslaugų sumažejo 41,3\% lyginant su $2015 \mathrm{~m}$. ir tik nežymiai išaugo psichologinio konsultavimo, socialinių ir laisvalaikio bei užimtumo organizavimo paslaugų kiekis.

Tyrimas parodè, kad siekiant sumažinti rehospitalizacijos priežastis, atskirtị tarp TPP ir bendruomenès, būtina skatinti ir užtikrinti jų tarpusavio bendradarbiavimą.

\section{Išvados}

1. TPP rehospitalizacijai turi įtakos statiniai (susiję su asmens ir šeimos kriminaline istorija) bei dinaminiai (susiję su asmens išsilavinimu, (ne)darbu, psichine sveikata, socialiniais ryšiais) veiksniai.

2. Tyrimo rezultatai rodo rizikos veiksnių įtaką tiriamųju rehospitalizacijai:

daugèja TPP, kurie augo daugiavaikèse šeimose bei kuriu šeimose buvo vartojamas alkoholis, buvo smurtaujama;

daugejja TPP su žemesniu išsilavinimu bei neturinčių profesinès kvalifikacijos;

daugejja TPP, gyvenančių kaime, neturinčių gyvenimo partnerio ar sutuoktinio bei nuosavo būsto, gyvenančiu su tèvais;
TPP socialiniai ryšiai su artimaisiais bei su draugais ar pažistamais tampa vis daugiau fragmentiški arba visai jų nelieka;

rehospitalizacija daugiau taikoma tiems TPP, kurie turi mažesnị darbingumo lygị, kurie pasyvesni darbo rinkoje, gyvena iš socialinių pašalpų bei nepripažista, jog serga psichikos liga;

TPP po PMP taikymo stacionare dažnai negauna institucijų bei artimujų paramos ar pagalbos;

pakartotinai hospitalizuotas kas antras TPP, pažeidęs ASPPSP sąlygas.

3. Rizikos veiksniai, turintys įtakos TPP rehospitalizacijai, yra susiję su kiekybiniais ir kokybiniais socialinio tinklo pokyčiais, užimtumo stoka, bedarbyste, ribotomis socialinio dalyvavimo galimybėmis.

\section{Literatūra}

1. Janušonis V. Tinkama sveikatos priežiūra: pakartotinè hospitalizacija - norma ar nepageidautinas įvykis. Sveikatos mokslai, 2014; 24(5): 92-99.

https://doi.org/10.5200/sm-hs.2014.0103

2. Lietuvos Respublikos baudžiamojo kodekso 98 straipsnis. Priverčiamosios medicinos priemonès // Žin., 2000; 89-2741.

3. Lietuvos Respublikos baudžiamojo proceso kodekso 392-406 straipsniai. Priverčiamųų medicinos priemonių taikymo procesas // Žin., 2002; 37-1341.

4. Lietuvos Respublikos sveikatos apsaugos ministro ir Lietuvos Respublikos socialinès apsaugos ir darbo ministro $2017 \mathrm{~m}$. sausio 19 d. įsakymas Nr. V-53/A1-32 „Dèl Lietuvos Respublikos sveikatos apsaugos ministro ir Lietuvos Respublikos socialinès apsaugos ir darbo ministro $2008 \mathrm{~m}$. liepos $10 \mathrm{~d}$. ịsakymo Nr. V-668/A1-243, „Dèl pacientų, teismo nutartimi pripažintų nepakaltinamais ir nukreiptų priverstinai gydytis, psichosocialinès reabilitacijos tvarkos aprašo patvirtinimo" pakeitimo" //Žin. 2008, Nr. 79-3162, galiojanti suvestinè nuo 2017-01-26.

5. Lietuvos Respublikos sveikatos apsaugos ministro $2012 \mathrm{~m}$. rugpjūčio 21 d. ịsakymas Nr. V-788 „,Dèl psichosocialinès reabilitacijos paslaugų psichikos sutrikimų turintiems asmenims teikimo tvarkos aprašo patvirtinimo“ // Žin., 2012; 100-5109.

6. Raškauskas V. Priverstinio hospitalizavimo psichiatrijoje paplitimas ir klinikiniai ypatumai. Daktaro disertacija, 2010. https:// epublications.vu.1t/object/elaba:2042937/index.html

7. Rokiškio psichiatrijos ligoninès dokumentai: pacientų gydymo istorijos (Forma Nr. 003/a), teismo psichiatrijos, teismo psichologijos ekspertizių aktai (Forma Nr. 192/a), teismo nutartys, buities ir gyvenimo sąlygų patikrinimo aktai (Forma patvirtinta LR SADM ministro 2012-01-25 įsakymu Nr. A1-35).

8. Ustinavičiūtė L. Lietuvos teisès pažeidèjų rizikos veiksnių, susijusių su pakartotiniu nusikalstamumu, analizė. Daktaro disertacija. Socialiniai mokslai, Psichologija, M.Romerio universitetas, 2012.

\section{THE BASIC REASONS OF}




\section{4}

\section{THE BASIC REASONS OF THE REHOSPITALIZATION OF FORENSIC PSYCHIATRIC PATIENTS}

J. Navickienė, E. Vaitiekus

Key words: forensic psychiatric patients, re-hospitalization. Summary

From mental illnesses suffer men and women of various ages, education and nationalities. In the recent decades, a large number of studies were performed, where were examined biological, psychosocial and social factors that affect on the mental disorders, as well as the re-hospitalization of the mentally disordered persons. In this article, on the base of the analysis of scientific literature and performed researches in PI Rokiškis Psychiatric Hospital, the spe- cific factors of the social mal-adaptation are identified for forensic psychiatric patients (mentally irresponsible) and the basic reasons of the re-hospitalization for the above-mentioned persons. The reasons of the re-hospitalization are caused by the entirety of the interacting factors: the qualitative and quantitative changes in the social network, lack of employment, unemployment, limited opportunities of the social participation, negative public attitude, discrimination and stigmatization.

Correspondence to: j.navickiene@rpl.1t

Gauta 2017-09-29 